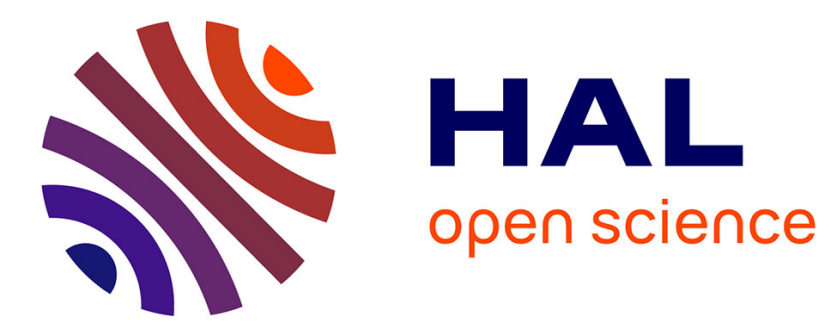

\title{
Meteoritic amino acids as chemical tracers of parent-body chemistries
}

Y. Ellinger, M. Lattelais, F. Pauzat, J-C Guillemin, B. Zanda

\section{To cite this version:}

Y. Ellinger, M. Lattelais, F. Pauzat, J-C Guillemin, B. Zanda. Meteoritic amino acids as chemical tracers of parent-body chemistries. Monthly Notices of the Royal Astronomical Society, 2021, 502 (3), pp.4064-4073. 10.1093/mnras/stab217 . hal-03281323

\section{HAL Id: hal-03281323 \\ https://hal.science/hal-03281323}

Submitted on 17 Nov 2021

HAL is a multi-disciplinary open access archive for the deposit and dissemination of scientific research documents, whether they are published or not. The documents may come from teaching and research institutions in France or abroad, or from public or private research centers.
L'archive ouverte pluridisciplinaire HAL, est destinée au dépôt et à la diffusion de documents scientifiques de niveau recherche, publiés ou non, émanant des établissements d'enseignement et de recherche français ou étrangers, des laboratoires publics ou privés. 


\title{
Meteoritic amino acids as chemical tracers of parent body chemistries
}

\author{
Y. Ellinger, ${ }^{1 \star}$ M. Lattelais, ${ }^{1}$ F. Pauzat ${ }^{1}$ J.-C. Guillemin ${ }^{2}$ and B. Zanda ${ }^{3}$ \\ ${ }^{1}$ Sorbonne Université, CNRS - UMR7616, LCT, 4 Place Jussieu, 75005 Paris, France \\ ${ }^{2}$ Univ Rennes, Ecole Nationale Supérieure de Chimie de Rennes, CNRS, ISCR UMR6226, F-35000 Rennes, France \\ ${ }^{3}$ Sorbonne Université, CNRS - UMR7202, MNHN, 61 rue Buffon, 75005 Paris, France
}

Accepted XXX. Received YYY; in original form ZZZ

\begin{abstract}
The analysis of the organic matter of meteorites made it possible to identify over 70 amino acids (AA), including 8 of those found in living organisms. However, their relative abundances vary drastically with the type of the carbonaceous chondrite, even for isomers of same chemical formula. In this report we address the question whether this difference may have its origin in the relative stability of these isomers according to the conditions they experienced when they were formed and after. To this end, we rely on the fact that for most of the species observed so far in the interstellar medium (ISM), the most abundant isomer of a given generic chemical formula is the most stable one (minimum energy principle (MEP)). Using quantum density functional theory (DFT) simulations, we investigate the relative stability of the lowest energy isomers of alanine (Ala) and amino butyric acid (ABA) in the neutral, protonated, and zwitterionic structures together with corresponding nitrile precursors. It is shown that $\beta$-alanine and $\gamma$-ABA are the most stable in a protonated form whereas $\alpha$-AA are the most stable in the zwitterionic structure. The different composition of the carbonaceous chondrites CIs and CMs could be linked to the chemical context of the aqueous alterations of the parent bodies.
\end{abstract}

Key words: Key words: ISM: molecules - meteorites - methods: numerical

\section{INTRODUCTION}

The idea of a possible input of organic matter from space to the building of the early bricks of life has really taken shape and received increasing attention following the recovery of the first carbonaceous chondrite. (Kvenvolden et al. 1970; Oro et al. 1971) Over 70 amino acids (AA) were isolated in the Murchison meteorite (fall in 1969), most of which were non-proteinogenic on Earth (Cronin \& Chang 1993), but eight out of the 22 present in living organisms were identified (Cooper et al. 1992). This suggests that meteorites could have played an important role in the origin of life, namely carbonaceous chondrites of Renazzo (CR), Murray (CM) and Ivuna (CI) types, an hypothesis reinforced by the presence of an enantiomeric excess in some of them (Botta et al. 2002; Botta \& Bada 2002; Botta et al. 2007; Martins \& Sephton 2009; Glavin et al. 2011). CIs have exactly the elemental composition of the Sun photosphere (except for the most volatile elements), which means that they consist of matter inherited from the Solar nebula almost without any chemical transformation.

^ E-mail: yves.ellinger@sorbonne-universite.fr
A consensus has developed that AA found in meteorites form via complex processes, but supposedly different for CM and CI chondrites (Ehrenfreund et al. 2001) in view of the difference of the amino acids compositions between the two families. The most plausible synthetic route to the AA detected in CM chondrites (Cronin et al. 1995) implies that the precursors, ammonia, hydrogen cyanide, aldehydes, and ketones existed or were formed in the protosolar nebula, and later incorporated in the asteroidal parent body where Strecker-cyanohydrine synthesis would have then taken place. For the amino acids in CI chondrites, another route was suggested implying ammonia and unsaturated nitriles (Botta \& Bada 2002). Among all AA, alanine (Ala), the first of them containing 3 carbon atoms, is one of the most abundant species of small molecular weight. Its abundance, as already remarked for the other AA, varies drastically with the type of chondrites (see e.g. Botta et al. (2002)). The relative abundance with respect to glycine (Gly), that contains 2 carbon atoms, has been considered as a possible indicator to trace the nature of the parent body, based on the plausible chemical mechanisms of AA formation. Another information to take into account is the fact that the relative abundance of the $\beta$ - to the $\alpha$-isomer 
$(\mathrm{D}+\mathrm{L})$ of Ala swaps from 0.75 to 15 between Murchison and Orgueil, i.e., between a CM and a CI chondrite.

In this report we address the question from a different angle that is to say whether this difference may have its origin in the relative stability of these two isomers depending on the conditions they experienced when they were formed (and/or destroyed), which may bring new constraints on the constitutions of the parent bodies. In other words, can the degree of aqueous alteration be a key factor able to influence the relative abundance of amino acids and distributions in carbonaceous chondrites? Whether this hypothesis(Botta et al. 2002; Glavin et al. 2011; Ehrenfreund et al. 2001; Rubin et al. 2011) can be generalized is investigated by considering AA containing 4 carbon atoms, i.e. the isomers of amino butyric acid (ABA). To the well documented studies mentioned above we added the results obtained recently on the organic matter found in the Paris meteorite (Martins et al. 2015; Elsila et al. 2016; Vinogradoff et al. 2017). One specificity of this meteorite is that it is considered to be the least aqueously altered carbonaceous CM chondrite analyzed so far. The following investigation makes use of theoretical results: i) A systematic study of the abundance ratios of species observed in different isomeric forms in the interstellar medium (ISM) has shown that the most abundant isomers of the same chemical formula are the most stable. This result (Lattelais et al. 2009, 2010) is based on state of the art computations of the stability of the isomers of same generic chemical formula, and the observations of their relative abundances towards astronomical sources available in the literature. We called this the minimum energy principle $(M E P)^{1}$, which can be seen as a simplification of the concept of the minimization of the Gibbs energy under thermodynamic equilibrium circumstances. Over the whole $\sim 200$ of extragalactic and interstellar molecules observed only a few exceptions can be found (less than $\sim 10 \%$ ). Among the many reasons advanced to rationalize these exceptions, the differential adsorption at the surface of interstellar ices could play a major role (Lattelais et al. 2011a; Ellinger et al. 2020), as shown by both quantum chemical simulations and/or thermal programmed desorption (TPD) experiments. Consequently, even if this principle is not an absolute rule, it can be used as a pragmatic tool to predict with a high efficiency which molecules should be the more abundant.

ii) An application of the MEP to the study of the isomers of glycine in different chemical environments showed (Lattelais et al. 2011b) that the relative stability of these different isomers varies drastically. We found that Gly is by far not the most stable species in neutral conditions, which may explain why it is so difficult to observe in the interstellar medium. Surprisingly enough, Gly becomes the most stable if protonated or if trapped in water or adsorbed on icy grains in a zwitterionic form.

In what follows we present a similar type of study for $\mathrm{C} 3$ and $\mathrm{C} 4$ amino acids (AA) namely, Ala and ABA derivatives, considering the neutral, protonated and zwitterionic

\footnotetext{
1 Here we use the word principle according to the definition given in the ARTFL Project, The University of Chicago (2001): In science, principle refers to laws which certain observations have first shown to be probable and to which the most extensive generality has then been given.
}

forms than can plausibly exist during the aqueous alteration period. In addition we present also the relative stability of the most important nitrile precursors. All these possibilities are discussed in the light of the MEP. The theoretical approach is summarized in Sect. 2 and the results are reported in Sect.3. The discussion of the consequences of our calculations is presented in the last section in a meteoritic context.

\section{THEORETICAL METHODS}

In an ideal situation, we would have used the highest possible level of post Hartree-Fock theory with extended basis sets to position the different isomers on the energy scale. However, in view of the large number of systems to consider, a balance has to be made between the level of theory and the computational efficiency. Hereafter, the compromise was to use density functional theory (DFT), coupling the B3LYP formalism with the standard 6-311G(d,p) basis set. This level of theory was designed for the best reproduction of the structural properties, energies and spectroscopic parameters (vibrations, dipole moments...) of normal organic molecules, namely, molecules well represented by a unique Lewis structure. Each structure, fully optimized, was verified to be a stationary point by vibrational analysis. All conformers were studied for each molecule but only the most stable one is reported here. For a comprehensive presentation of DFT methods and their applications, the reader should refer to Lee \& Scuseria (1995)(Lee \& Scuseria 1995) and Koch \& Holthausen (2001)(Koch \& Holthausen 2001).

For the treatment of zwitterionic forms, a recent study of Gly isomers (Lattelais et al. 2011b) showed that using post Hartree-Fock MP2 was at least necessary to properly describe correlations effects in this case. This level of theory, associated with diffuse atomic functions is used here, coupled with the polarizable continuum model (PCM) to simulate the water environment (Tomasi \& Persico 1994) during the hydration phase of the meteorite or parent body. The volume of the cavity in which the AA zwitterion is confined in the continuum has been enlarged to account for the spatial extension of the electronic density by adding a polarizable domain around the hydrogen atoms.

The relative energies reported here include zero point vibrational effects. All calculations were performed using the GAUSSIAN09 package(Frish et al. 2009).

\section{RELATIVE STABILITIES OF GLYCINE, ALANINE, AMINO BUTYRIC ACID AND AMINO NITRILES PRECURSORS}

Limiting the analysis to glycine, the first aminoacid of $[2 \mathrm{C}, 5 \mathrm{H}, 2 \mathrm{O}, \mathrm{N}]$ formula, does not allow any general conclusion about the behavior of (AA) in meteoritic environments because it is the only compound possible with a $-\mathrm{COOH}$ and a $-\mathrm{NH}_{2}$ functional groups in its family. The next amino acids of $[3 \mathrm{C}, 7 \mathrm{H}, 2 \mathrm{O}, \mathrm{N}]$ and $[4 \mathrm{C}, 9 \mathrm{H}, 2 \mathrm{O}, \mathrm{N}]$ formulae are then added to the study since they can appear under several isomeric forms with the same two $-\mathrm{COOH}$ and $-\mathrm{NH}_{2}$ functional groups in their families. More precisely, this choice covers the first basic series possible for (AA) and derivatives that can be formed with the $[2 \mathrm{C}, 5 \mathrm{H}, 2 \mathrm{O}, \mathrm{N}],[3 \mathrm{C}, 7 \mathrm{H}, 2 \mathrm{O}, \mathrm{N}]$ and 
$[4 \mathrm{C}, 9 \mathrm{H}, 2 \mathrm{O}, \mathrm{N}]$ sets of atoms. These 3 series include the simplest AA (Gly), the first ramified $\alpha$-AA of biological interest $(\alpha$-Ala) and its linear sibling ( $\beta$-Ala) to which add five amino acid isomers of the aminobutyric acid (ABA family) listed below:

$\gamma$-ABA, i.e. $\mathrm{NH}_{2} \mathrm{CH}_{2} \mathrm{CH}_{2} \mathrm{CH}_{2} \mathrm{COOH}$

$\alpha$-ABA i.e. $\mathrm{CH}_{3} \mathrm{CH}_{2} \mathrm{CH}\left(\mathrm{NH}_{2}\right) \mathrm{COOH}$,

$\beta$-ABA i.e. $\mathrm{NH}_{2} \mathrm{CH}\left(\mathrm{CH}_{3}\right) \mathrm{CH}_{2} \mathrm{COOH}$,

AIB i.e. $\mathrm{NH}_{2} \mathrm{C}\left(\mathrm{CH}_{3}\right)_{2} \mathrm{COOH}$,

$\beta$-AIB i.e. $\mathrm{NH}_{2} \mathrm{CH}_{2} \mathrm{CH}\left(\mathrm{CH}_{3}\right) \mathrm{COOH}$,

It should be noticed that none of these five isomers enters protein formation. ${ }^{2}$ The cyclic isomers and those containing an NO bond were not considered for energetic reasons(Chiaramello et al. 2010; Lattelais et al. 2010)

\section{1 a) Neutral glycine, alanine and amino butyric acid isomers}

The relative stabilities of the different Gly isomers have already been discussed in relation with the non observation of this compound in the ISM(Lattelais et al. 2011b). Hereafter we focus on the structures obtained by substituting, one at a time, an $\mathrm{H}$ of Gly isomers by a $\mathrm{CH}_{3}$ group (Table 1 ). We consider only the isomers that contain a carboxyl group or an amino group, those with a formyl group being much higher in energy according to our previous study. As for $[2 \mathrm{C}, 5 \mathrm{H}, 2 \mathrm{O}, \mathrm{N}]$, the most stable isomer of the $[3 \mathrm{C}, 7 \mathrm{H}, 2 \mathrm{O}, \mathrm{N}]$ system is a carbamic acid, $\mathrm{CH}_{3}-\mathrm{CH}_{2}-\mathrm{NH}-\mathrm{COOH}$, not Ala.

It should be noted that this compound is obtained by replacement of an $\mathrm{H}$ of the methyl group in the most stable Gly isomer $\mathrm{CH}_{3}-\mathrm{NH}-\mathrm{COOH}$, by $\mathrm{CH}_{3}$. The next compound on the energy scale is a carbamate, $\mathrm{CH}_{3}-\mathrm{CH}_{2}-\mathrm{O}-\mathrm{CO}-\left(\mathrm{NH}_{2}\right)$, also obtained by $\mathrm{H} / \mathrm{CH}_{3}$ substitution on the second more stable isomer $\mathrm{CH}_{3}-\mathrm{O}-\mathrm{CO}-\left(\mathrm{NH}_{2}\right)$ of the Gly series. The energy separations are comparable, namely 3.3 and $4.7 \mathrm{kcal} / \mathrm{mol}$ for the alanine and Gly series respectively. Three other compounds including lactamide, $\mathrm{HO}-\mathrm{CH}\left(\mathrm{CH}_{3}\right)-\mathrm{CO}-\left(\mathrm{NH}_{2}\right)$, a precursor of biological lactic acid, are found on the energy scale below biological $\alpha$-Ala. In fact, both $\alpha$ - and $\beta$-Ala are close in energy, $\sim 11 \mathrm{kcal} / \mathrm{mol}$ over the most stable isomer. This energy separation is close to that of $10.6 \mathrm{kcal} / \mathrm{mol}$ between Gly and its most stable isomer. In both series, the $\alpha$-AA structure is not energetically favored. Another $\alpha$-AA, sarcosine, $\mathrm{CH}_{3}-\mathrm{NH}-\mathrm{CH}_{2}-\mathrm{COOH}$, also found in the Murchison carbonaceous chondrite(Pizzarello et al. 2004) appears even higher in energy, namely, $\sim 7.5 \mathrm{kcal} / \mathrm{mol}$ over $\alpha$-Ala.

The same protocol is used for the ABA isomers, i.e. the $[4 \mathrm{C}, 9 \mathrm{H}, 2 \mathrm{O}, \mathrm{N}]$ set of atoms. The different structures are obtained by substituting a $\mathrm{H}$ atom of the neutral isomers of Ala by a $\mathrm{CH}_{3}$ group. The results are presented in Table 1.

The lowest energy isomer is the $\mathrm{N}$-isopropyl carbamic acid $\left(\mathrm{CH}_{3}\right)_{2} \mathrm{CHNHCOOH}$. It is the structure coming from the replacement of $\mathrm{H}$ of the $\mathrm{CH}_{2}$ methylene by $\mathrm{CH}_{3}$ on the N-ethyl carbamic acid $\mathrm{CH}_{3} \mathrm{CH}_{2} \mathrm{NHCOOH}$ that is the most stable structure of the $[3 \mathrm{C}, 7 \mathrm{H}, 2 \mathrm{O}, \mathrm{N}]$ set of atoms. In the same way, the second isomer is the isopropyl carbamate,

2 Although not constituent of proteins, $\gamma$-ABA, i.e. $\mathrm{NH}_{2} \mathrm{CH}_{2} \mathrm{CH}_{2} \mathrm{CH}_{2} \mathrm{COOH}$ plays

an important biochemical role since it is active in the mechanism of neurotransmission.
$\left(\mathrm{CH}_{3}\right)_{2} \mathrm{CHOCONH}_{2}$ arising from the same type of $\mathrm{H} / \mathrm{CH}_{3}$ replacement on the ethyl carbamate $\mathrm{CH}_{3} \mathrm{CH}_{2} \mathrm{OCONH}_{2}$ that is second on the Ala energy scale.

In third position one finds $\mathrm{N}$-propyl carbamic acid $\mathrm{CH}_{3}-$ $\mathrm{CH}_{2}-\mathrm{CH}_{2}-\mathrm{NH}-\mathrm{COOH}$ practically at the same energy as isopropyl carbamate above the most stable $\mathrm{N}$-isopropyl carbamic acid, both compounds deriving formally from N-ethyl carbamic acid. Next on the energy scale one has n-propyl carbamate $\mathrm{CH}_{3} \mathrm{CH}_{2} \mathrm{CH}_{2} \mathrm{OCONH}_{2}$ obtained directly from its analogue ethyl carbamate by the formal $\mathrm{H} / \mathrm{CH}_{3}$ replacement.

The first $\alpha$-AA, $\mathrm{NH}_{2} \mathrm{C}\left(\mathrm{CH}_{3}\right)_{2} \mathrm{COOH}$ is $10.8 \mathrm{kcal} / \mathrm{mol}$ above the most stable isomer. Such energy separation is similar to those between $\alpha$-Ala and Gly with respect to the lowest energy carbamic acids isomers in their respectives series, i.e. $\sim 10.7 \mathrm{kcal} / \mathrm{mol}$. Much higher in energy is found $\gamma-\mathrm{ABA}$, at $14 \mathrm{kcal} / \mathrm{mol}$.

The remarkable result to keep in mind is that the most stable species are the alkyl carbamic acids, followed by carbamates. None of the AA is the most stable compound of the 3 series, which may be a plausible reason for the lack of detection in the ISM gas phase (Lattelais et al. 2011b). However, carbamic acids are kinetically very unstable compounds in any Earth conditions giving the corresponding amines while carbamates are slowly hydrolyzed in the corresponding amines and alcohols. Thus, amides give amines and carboxylic acids, reactions dramatically accelerated in water, whatever the conditions, basic or acidic. It means that, in the list of Table 1, only amino acids can survive for a very long time in the neutral, acidic or basic aqueous media inside meteorites.

\section{2 b) Protonated glycine, alanine and amino butyric acid isomers}

As for glycine we consider all the $[3 \mathrm{C}, 7 \mathrm{H}, 2 \mathrm{O}, \mathrm{N}] \mathrm{H}^{+}$and $[4 \mathrm{C}, 9 \mathrm{H}, 2 \mathrm{O}, \mathrm{N}] \mathrm{H}^{+}$structures that are possible when a proton is attached to the neutral isomers. As shown in Table 2, the isomers of the protonated AA are now the most stable, unlike their neutral parents.

The most stable structures are those with the longest carbon chain i.e. $\beta$ - $\mathrm{Ala}\left(\mathrm{H}^{+}\right)$and $\gamma-\mathrm{ABA}\left(\mathrm{H}^{+}\right)$. In the case of $[3 \mathrm{C}, 7 \mathrm{H}, 2 \mathrm{O}, \mathrm{N}] \mathrm{H}^{+}$the lowest energy compound is $\beta$-Ala $\left(\mathrm{H}^{+}\right)$ whose enhanced stability can be rationalized by the possible formation of a 6 -membered cycle closed by a hydrogen bond between a hydrogen of the protonated amine and the oxygen of the $\mathrm{C}=\mathrm{O}$ group. This structure is more stable than the 5membered cycle that can be formed by $\alpha$-Ala $\left(\mathrm{H}^{+}\right)$, which is consistent with a position $\sim 6 \mathrm{kcal} / \mathrm{mol}$ higher on the energy scale.

In the case of $[4 \mathrm{C}, 9 \mathrm{H}, 2 \mathrm{O}, \mathrm{N}] \mathrm{H}^{+}$the lowest energy compound is $\gamma-\mathrm{ABA}\left(\mathrm{H}^{+}\right)$. Here the hydrogen bonded cycle is a 7-membered structure, a priori less stable than the 6membered one. In fact, $\gamma-\mathrm{ABA}\left(\mathrm{H}^{+}\right)$is followed on the energy scale by the protonated forms of $\beta$-Ala substituted by $\mathrm{H} / \mathrm{CH}_{3}$ replacements on all possible sites, i.e .

\section{$\beta-\mathrm{ABA}\left(\mathrm{H}^{+}\right), \mathrm{NH}_{3}^{+} \mathrm{CH}\left(\mathrm{CH}_{3}\right) \mathrm{CH}_{2} \mathrm{COOH}$}

$\beta$ - $\mathrm{AIB}\left(\mathrm{H}^{+}\right), \mathrm{NH}_{3}^{+} \mathrm{CH}_{2} \mathrm{CH}\left(\mathrm{CH}_{3}\right) \mathrm{COOH}$,

$\mathrm{N}$-methyl $\beta$-alanine $\left(\mathrm{H}^{+}\right), \mathrm{CH}_{3} \mathrm{NH}_{2}^{+} \mathrm{CH}_{2} \mathrm{CH}_{2} \mathrm{COOH}$, all of them able to give 6 -membered cycles. The reason is to be found in the destabilizing steric interactions due to the $\mathrm{CH}_{3}$ substituents. 
Table 1. Relative thermodynamic stability of glycine, alanine and amino butyric acid neutral isomers (kcal/mol)

\begin{tabular}{|c|c|c|c|c|c|}
\hline $\begin{array}{l}\text { Neutral } \\
\text { Glycine isomers }\end{array}$ & $\Delta \mathrm{E}$ & $\begin{array}{l}\text { Neutral } \\
\text { Alanine isomers }\end{array}$ & $\Delta \mathrm{E}$ & $\begin{array}{l}\text { Neutral } \\
\text { ABA isomers }\end{array}$ & $\Delta \mathrm{E}$ \\
\hline $\mathrm{CH}_{3}-\mathrm{NH}-\mathrm{COOH}$ & 0.0 & $\mathrm{CH}_{3}-\mathrm{CH}_{2}-\mathrm{NH}-\mathrm{COOH}$ & 0.0 & $\left(\mathrm{CH}_{3}\right)_{2} \mathrm{CH}-\mathrm{NH}-\mathrm{COOH}$ & 0.0 \\
\hline $\mathrm{CH}_{3}-\mathrm{OCO}\left(\mathrm{NH}_{2}\right)$ & 4.7 & $\mathrm{CH}_{3}-\mathrm{CH}_{2}-\mathrm{OCO}\left(\mathrm{NH}_{2}\right)$ & 3.3 & $\left(\mathrm{CH}_{3}\right)_{2} \mathrm{CH}-\mathrm{OCO}\left(\mathrm{NH}_{2}\right)$ & 1.9 \\
\hline $\mathrm{NH}_{2} \mathrm{CH}_{2} \mathrm{COOH}$ & 10.3 & $\left(\mathrm{CH}_{3}\right)_{2} \mathrm{~N}-\mathrm{COOH}$ & 7.0 & $\mathrm{CH}_{3}-\mathrm{CH}_{2}-\mathrm{CH}_{2}-\mathrm{NH}-\mathrm{COOH}$ & 2.0 \\
\hline $\mathrm{HOCH}_{2}-\mathrm{CO}\left(\mathrm{NH}_{2}\right)$ & 12.0 & $\mathrm{HOCH}\left(\mathrm{CH}_{3}\right)-\mathrm{CO}\left(\mathrm{NH}_{2}\right)$ & 10.3 & $\mathrm{CH}_{3}-\mathrm{CH}_{2}-\mathrm{CH}_{2}-\mathrm{O}-\mathrm{CO}\left(\mathrm{NH}_{2}\right)$ & 5.4 \\
\hline $\mathrm{HOCH}_{2} \mathrm{NHCHO}$ & 18.0 & $\mathrm{CH}_{3}-\mathrm{OCONH}-\mathrm{CH}_{3}$ & 10.6 & $\mathrm{CH}_{3}-\mathrm{CH}_{2}-\mathrm{N}-\left(\mathrm{CH}_{3}\right) \mathrm{COOH}$ & 7.8 \\
\hline \multirow[t]{12}{*}{$\mathrm{NH}_{2} \mathrm{CH}_{2} \mathrm{OCHO}$} & 30.8 & $\mathrm{NH}_{2} \mathrm{CH}\left(\mathrm{CH}_{3}\right)-\mathrm{COOH}$ & 10.8 & $\left(\mathrm{CH}_{3}\right)_{2} \mathrm{C}(\mathrm{OH})-\mathrm{CO}\left(\mathrm{NH}_{2}\right)$ & 8.9 \\
\hline & & $\mathrm{NH}_{2} \mathrm{CH}_{2}-\mathrm{CH}_{2}-\mathrm{COOH}$ & 11.5 & $\mathrm{CH}_{3}-\mathrm{CH}(\mathrm{OH})-\mathrm{CH}_{2}-\mathrm{CO}\left(\mathrm{NH}_{2}\right)$ & 9.7 \\
\hline & & $\mathrm{HOCH}_{2}-\mathrm{CH}_{2}-\mathrm{CO}\left(\mathrm{NH}_{2}\right)$ & 11.7 & $\mathrm{CH}_{3}-\mathrm{CH}\left(\mathrm{NH}_{2}\right)-\mathrm{CH}_{2}-\mathrm{COOH}$ & 10.7 \\
\hline & & $\mathrm{HOCH}_{2}-\mathrm{CO}-\mathrm{NH}-\mathrm{CH}_{3}$ & 17.8 & $\mathrm{NH}_{2} \mathrm{C}\left(\mathrm{CH}_{3}\right)_{2}-\mathrm{COOH}$ & 10.8 \\
\hline & & $\mathrm{CH}_{3}-\mathrm{NH}-\mathrm{CH}_{2}-\mathrm{COOH}$ & 18.3 & $\mathrm{CH}_{3}-\mathrm{CH}_{2}-\mathrm{CH}(\mathrm{OH})-\mathrm{CO}\left(\mathrm{NH}_{2}\right)$ & 12.1 \\
\hline & & $\mathrm{CH}_{3}-\mathrm{O}-\mathrm{CH}_{2}-\mathrm{CO}-\left(\mathrm{NH}_{2}\right)$ & 21.2 & $\mathrm{NH}_{2} \mathrm{CH}_{2}-\mathrm{CH}\left(\mathrm{CH}_{3}\right)-\mathrm{COOH}$ & 12.3 \\
\hline & & & & $\mathrm{CH}_{3}-\mathrm{CH}_{2}-\mathrm{CH}\left(\mathrm{NH}_{2}\right)-\mathrm{COOH}$ & 13.9 \\
\hline & & & & $\mathrm{NH}_{2} \mathrm{CH}_{2}-\mathrm{CH}_{2}-\mathrm{CH}_{2}-\mathrm{COOH}$ & 14.0 \\
\hline & & & & $\mathrm{HOCH}_{2}-\mathrm{CH}\left(\mathrm{CH}_{3}\right)-\mathrm{CO}\left(\mathrm{NH}_{2}\right)$ & 14.1 \\
\hline & & & & $\mathrm{HOCH}_{2}-\mathrm{CH}_{2}-\mathrm{CH}_{2}-\mathrm{CO}\left(\mathrm{NH}_{2}\right)$ & 14.4 \\
\hline & & & & $\mathrm{CH}_{3}-\mathrm{CH}_{2}-\mathrm{NH}-\mathrm{CH}_{2}-\mathrm{COOH}$ & 18.3 \\
\hline & & & & $\mathrm{CH}_{3}-\mathrm{NH}-\mathrm{CH}\left(\mathrm{CH}_{3}\right)-\mathrm{COOH}$ & 18.5 \\
\hline
\end{tabular}

The $\alpha$-AA $\left(\mathrm{H}^{+}\right)$i.e. $\mathrm{AIB}\left(\mathrm{H}^{+}\right)(9 \mathrm{kcal} / \mathrm{mol}), \alpha$ - $\mathrm{ABA}\left(\mathrm{H}^{+}\right)$, $\mathrm{CH}_{3} \mathrm{CH}_{2} \mathrm{CH}\left(\mathrm{NH}_{3}^{+}\right) \mathrm{COOH}(12 \mathrm{kcal} / \mathrm{mol})$, protonated $\mathrm{N}$ methyl alanine, $\mathrm{CH}_{3} \mathrm{NH}_{2}^{+} \mathrm{CH}\left(\mathrm{CH}_{3}\right) \mathrm{COOH}(\sim 13 \mathrm{kcal} / \mathrm{mol})$, protonated N-ethyl glycine, $\mathrm{CH}_{3} \mathrm{CH}_{2} \mathrm{NH}_{2}^{+} \mathrm{CH}_{2} \mathrm{COOH}$ $(\sim 13 \mathrm{kcal} / \mathrm{mol})$ and protonated dimethyl glycine, $\left(\mathrm{CH}_{3}\right)_{2} \mathrm{NH}^{+} \mathrm{CH}_{2} \mathrm{COOH} \quad(\sim 18 \mathrm{kcal} / \mathrm{mol})$ are all higher in energy.

Protonation of the oxygen atoms of the neutral Ala and ABA isomers leads in all cases to either the transfer of the proton to the nitrogen atom or to dissociation. Stable protonation of the oxygen occurs only when the $\mathrm{C}=\mathrm{O}$ and $\mathrm{N}$ atom are linked together; in all other cases, $\mathrm{H}^{+}$attaches to nitrogen.

\section{3 c) Zwitterionic glycine, alanine and amino butyric acid isomers}

In the presence of water, i.e. the aqueous alteration phase, $\mathrm{AA}$ are known to be in zwitterionic form, this intramolecular ion pair being unstable in the gas phase. Theoretically, it has been shown that as few as two $\mathrm{H}_{2} \mathrm{O}$ molecules, when properly positioned around glycine, are sufficient to induce the proton transfer from the carboxylic group to the amino group leading to the $\mathrm{NH}_{3}^{+} \mathrm{CH}_{2} \mathrm{COO}^{-}$zwitterion (Kassab et al. 2000).

Taking the dielectric constant of liquid water $(\epsilon=80)$ to describe the environment in the PCM model (Tomasi \& Persico 1994) we obtain the energetic orders given in Table 3. Primary amino groups produce more stable zwitterions than secondary and tertiary groups. The important result is that the $\alpha$-AA are the most thermodynamically stable structures, those able to participate in the chiral structures of biologic interest.

\section{4 d) Nitrile precursors of glycine, alanine and amino butyric acid}

The Strecker synthesis has been proposed to be at the origin of the AA in meteorites (Peltzer et al. 1984; Ehrenfreund et al. 2001; Bernstein et al. 2004). Starting from $\mathrm{HCN}, \mathrm{NH}_{3}$ and a carbonyl compound it produces amino nitriles that lead to the corresponding $\alpha$-AA after hydrolysis. This same mechanism was proposed earlier (Brown et al. 1977) for the formation of interstellar Gly but it has taken 10 more years to detect amino acetonitrile $\mathrm{NH}_{2} \mathrm{CH}_{2} \mathrm{CN}$ in Sgr B2 (Belloche et al. 2008).

Hereafter, the relative energies of the nitriles assumed to be precursors of $\mathrm{C} 2, \mathrm{C} 3$ and $\mathrm{C} 4$ amino acids are reported in Table 4 . The most stable species that can be formed from the $[2 \mathrm{C}, 4 \mathrm{H}, 2 \mathrm{~N}],[3 \mathrm{C}, 6 \mathrm{H}, 2 \mathrm{~N}]$ and $[4 \mathrm{C}, 8 \mathrm{H}, 2 \mathrm{~N}]$ atomic distributions contain the -CN group.

In acidic water, the corresponding acid are formed. Furthermore all of them are $\alpha$-amino nitriles, i.e. those leading to the most stable AA zwitterions by hydrolysis. Immediately above the amino nitrile isomers one finds the -NH-CN group at the end of the carbon chains $(\sim 3 \mathrm{kcal} / \mathrm{mol}$ up the energy scale). Higher in energy, the -HN- group is inserted in the carbon chains.

\section{DISCUSSION}

The aim of the present work was to determine whether differences in the abundance ratios of $\beta$ - to $\alpha$-Ala (see data by Botta et al. (2002)(Botta \& Bada 2002), Botta et al. (2007)(Botta et al. 2007), Martins \& Sephton (2009)(Martins \& Sephton 2009), Glavin et al. (2011)(Glavin et al. 2011) and Martins et al. (2015)(Martins et al. 2015) in Tables 5 and 6 , could be related to a chemical environment that would ultimately be linked to the type of carbonaceous chondrite in which they are found. Based on the minimum energy principle, we find that all $\alpha$-, $\beta$ - and $\gamma$-AA are far from being the most stable isomers that can be formed from the neutral $[3 \mathrm{C}, 7 \mathrm{H}, 2 \mathrm{O}, \mathrm{N}]$ and $[4 \mathrm{C}, 9 \mathrm{H}, 2 \mathrm{O}, \mathrm{N}]$ set of atoms (see Table 
Table 2. Relative thermodynamic stability of glycine, alanine and amino butyric protonated isomers (kcal/mol)

\begin{tabular}{|c|c|c|c|c|c|}
\hline $\begin{array}{l}\text { Prootonated } \\
\text { Glycine isomers }\end{array}$ & $\Delta \mathrm{E}$ & $\begin{array}{l}\text { Protonated } \\
\text { Alanine isomers }\end{array}$ & $\Delta \mathrm{E}$ & $\begin{array}{l}\text { protonated } \\
\text { ABA isomers }\end{array}$ & $\Delta \mathrm{E}$ \\
\hline $\mathrm{NH}_{3}^{+}-\mathrm{CH}_{2}-\mathrm{COOH}$ & 0.0 & $\mathrm{NH}_{3}^{+}-\mathrm{CH}_{2}-\mathrm{CH}_{2}-\mathrm{COOH}$ & 0.0 & $\mathrm{NH}_{3}^{+}-\mathrm{CH}_{2}-\mathrm{CH}_{2}-\mathrm{CH}_{2}-\mathrm{COOH}$ & 0.0 \\
\hline $\mathrm{CH}_{3}-\mathrm{NH}-\mathrm{C}(\mathrm{OH})_{2}^{+}$ & 2.2 & $\mathrm{NH}_{3}^{+}-\mathrm{CH}\left(\mathrm{CH}_{3}\right)-\mathrm{COOH}$ & 5.8 & $\mathrm{NH}_{3}^{+}-\mathrm{CH}\left(\mathrm{CH}_{3}\right)-\mathrm{CH}_{2}-\mathrm{COOH}$ & 2.4 \\
\hline $\mathrm{CH}_{3}-\mathrm{O}-\mathrm{C}(\mathrm{OH})^{+}-\mathrm{NH}_{2}$ & 4.7 & $\mathrm{HO}-\mathrm{CH}_{2}-\mathrm{CH}_{2}-\mathrm{C}(\mathrm{OH})^{+}-\mathrm{NH}_{2}$ & 6.5 & $\mathrm{NH}_{3}^{+}-\mathrm{CH}_{2}-\mathrm{CH}\left(\mathrm{CH}_{3}\right)-\mathrm{COOH}$ & 5.9 \\
\hline $\mathrm{HOCH}_{2}-\mathrm{CH}_{2}-\mathrm{C}\left(\mathrm{OH}^{+}\right)-\mathrm{NH}_{2}$ & 6.0 & $\mathrm{CH}_{3}-\mathrm{CH}_{2}-\mathrm{O}-\mathrm{C}(\mathrm{OH})^{+}-\mathrm{NH}_{2}$ & 9.5 & $\mathrm{CH}_{3}-\mathrm{NH}_{2}^{+}-\mathrm{CH}_{2}-\mathrm{CH}_{2}-\mathrm{COOH}$ & 6.6 \\
\hline $\mathrm{NH}_{3}^{+}-\mathrm{CH}_{2}-\mathrm{COOH}$ & 15.4 & $\mathrm{CH}_{3}-\mathrm{CH}_{2}-\mathrm{NH}-\mathrm{C}(\mathrm{OH})_{2}^{+}$ & 9.6 & $\mathrm{HO}-\left(\mathrm{CH}_{2}\right)_{3}-\mathrm{C}(\mathrm{OH})^{+}-\mathrm{NH}_{2}$ & 7.8 \\
\hline $\mathrm{HOCH}_{2} \mathrm{NH}-\mathrm{CH}(\mathrm{OH})^{+}$ & 16.0 & $\mathrm{CH}_{3}-\mathrm{NH}_{2}^{+}-\mathrm{CH}_{2}-\mathrm{COOH}$ & 10.2 & $\mathrm{NH}_{3}^{+}-\mathrm{C}\left(\mathrm{CH}_{3}\right)_{2}-\mathrm{COOH}$ & 8.6 \\
\hline $\mathrm{NH}_{3}^{+} \mathrm{CH}=\mathrm{C}(\mathrm{OH})_{2}$ & 19.9 & $\mathrm{HO}-\mathrm{CH}\left(\mathrm{CH}_{3}\right)-\mathrm{C}(\mathrm{OH})^{+}-\mathrm{NH}_{2}$ & 11.2 & $\mathrm{HO}-\mathrm{CH}\left(\mathrm{CH}_{3}\right)-\mathrm{CH}_{2}-\mathrm{C}(\mathrm{OH})^{+}-\mathrm{NH}_{2}$ & 9.2 \\
\hline \multirow[t]{6}{*}{$\mathrm{NH}_{3}^{+} \mathrm{CH}(\mathrm{OH})-\mathrm{CHO}$} & 27.9 & $\left(\mathrm{CH}_{3}\right)_{2} \mathrm{~N}-\mathrm{C}(\mathrm{OH})_{2}^{+}$ & 14.2 & $\mathrm{CH}_{3}-\mathrm{CH}_{2}-\mathrm{CH}\left(\mathrm{NH}_{3}^{+}\right)-\mathrm{COOH}$ & 12.5 \\
\hline & & $\mathrm{HO}-\mathrm{CH}_{2}-\mathrm{C}(\mathrm{OH})^{+}-\mathrm{NH}-\mathrm{CH}_{3}$ & 16.2 & $\mathrm{CH}_{3}-\mathrm{NH}_{2}^{+}-\mathrm{CH}\left(\mathrm{CH}_{3}\right)-\mathrm{COOH}$ & 12.9 \\
\hline & & $\mathrm{CH}_{3}-\mathrm{O}-\mathrm{C}(\mathrm{OH})^{+}-\mathrm{NH}-\mathrm{CH}_{3}$ & 16.3 & $\mathrm{CH}_{3}-\mathrm{CH}_{2}-\mathrm{NH}_{2}^{+}-\mathrm{CH}_{2}-\mathrm{COOH}$ & 13.0 \\
\hline & & $\mathrm{NH}_{3}^{+}-\mathrm{CH}_{2} \mathrm{CH}=\mathrm{C}(\mathrm{OH})_{2}$ & 21.5 & $\left(\mathrm{CH}_{3}\right)_{2} \mathrm{CH}-\mathrm{O}-\mathrm{C}(\mathrm{OH})^{+}-\mathrm{NH}_{2}$ & 14.1 \\
\hline & & & & $\left(\mathrm{CH}_{3}\right)_{2} \mathrm{CH}-\mathrm{NH}-\mathrm{C}(\mathrm{OH})^{+}-\mathrm{OH}$ & 15.4 \\
\hline & & & & $\left(\mathrm{CH}_{3}\right)_{2} \mathrm{C}(\mathrm{OH})-\mathrm{C}(\mathrm{OH})^{+}-\mathrm{NH}_{2}$ & 15.9 \\
\hline
\end{tabular}

Table 3. Relative thermodynamic stability* of zwitterionic glycine, alanine and amino butyric acid isomers (kcal/mol).

\begin{tabular}{|c|c|c|c|c|c|}
\hline $\begin{array}{l}\text { Zwitterionic } \\
\text { Glycine isomers }\end{array}$ & $\Delta \mathrm{E}$ & $\begin{array}{l}\text { Zwitterionic } \\
\text { Alanine isomers }\end{array}$ & $\Delta \mathrm{E}$ & $\begin{array}{l}\text { Zwitterionic } \\
\text { ABA isomers }\end{array}$ & $\Delta \mathrm{E}$ \\
\hline $\begin{array}{l}\mathrm{NH}_{3}^{+}-\mathrm{CH}_{2}-\mathrm{COO}^{-} \\
\mathrm{CH}_{3}-\mathrm{NH}^{+}-\mathrm{COO}^{-}\end{array}$ & $\begin{array}{l}0.0 \\
3.3\end{array}$ & $\begin{array}{l}\mathrm{NH}_{3}^{+}-\mathrm{CH}\left(\mathrm{CH}_{3}\right)-\mathrm{COO}^{-} \\
\mathrm{NH}_{3}^{+}-\mathrm{CH}_{2}-\mathrm{CH}_{2}-\mathrm{COO}^{-} \\
\mathrm{CH}_{3}-\mathrm{CH}_{2}-\mathrm{NH}_{2}^{+}-\mathrm{COO}^{-} \\
\mathrm{CH}_{3}-\mathrm{NH}_{2}^{+}-\mathrm{CH}_{2}-\mathrm{COO}^{-} \\
\left(\mathrm{CH}_{3}\right)_{2} \mathrm{NH}^{+} \mathrm{COO}^{-}\end{array}$ & $\begin{array}{c}0.0 \\
0.5 \\
3.7 \\
8.7 \\
10.2\end{array}$ & $\begin{array}{l}\mathrm{NH}_{3}^{+}-\mathrm{C}\left(\mathrm{CH}_{3}\right)_{2}-\mathrm{COO}^{-} \\
\mathrm{NH}_{3}^{+}-\mathrm{CH}\left(\mathrm{CH}_{3}\right)-\mathrm{CH}_{2}-\mathrm{COO}^{-} \\
\mathrm{NH}_{3}^{+}-\mathrm{CH}_{2}-\mathrm{CH}\left(\mathrm{CH}_{3}\right)-\mathrm{COO}^{-} \\
\mathrm{CH}_{3}-\mathrm{CH}_{2}-\mathrm{CH}\left(\mathrm{NH}_{3}^{+}\right)-\mathrm{COO}^{-} \\
\left(\mathrm{CH}_{3}\right)_{2} \mathrm{CH}_{-} \mathrm{NH}_{2}^{+}-\mathrm{COO}^{-} \\
\mathrm{NH}_{3}^{+}-\left(\mathrm{CH}_{2}\right)_{3}-\mathrm{COO}^{-} \\
\mathrm{CH}_{3}-\mathrm{CH}_{2}-\mathrm{CH}_{2}-\left(\mathrm{NH}_{2}^{+}\right)-\mathrm{COO}^{-} \\
\mathrm{CH}_{3}-\mathrm{NH}_{2}^{+}-\mathrm{CH}_{2}-\mathrm{CH}_{2}-\mathrm{COO}^{-} \\
\left.\mathrm{CH}_{3}-\mathrm{NH}_{2}^{+}-\mathrm{CH}^{-} \mathrm{CH}_{3}\right)-\mathrm{COO}^{-} \\
\mathrm{CH}_{3}-\mathrm{CH}_{2}-\mathrm{NH}_{2}^{+}-\mathrm{CH}_{2}-\mathrm{COO}^{-} \\
\mathrm{CH}_{3}-\mathrm{CH}_{2}-\mathrm{NH}^{+}-\left(\mathrm{CH}_{3}\right)-\mathrm{COO}^{-} \\
\left(\mathrm{CH}_{3}\right)_{2} \mathrm{NH}^{+}-\mathrm{CH}_{2}-\mathrm{COO}^{-}\end{array}$ & $\begin{array}{c}0.0 \\
0.8 \\
3.2 \\
3.8 \\
4.0 \\
4.9 \\
7.1 \\
10.5 \\
10.6 \\
10.9 \\
11.7 \\
17.3\end{array}$ \\
\hline
\end{tabular}

* All calculations in this table are carried out at the MP2/6-311+G**level. The difference between the energies of the lowest two isomers of the C3 (Ala) is rather low $(\Delta \mathrm{E} 0.46 \mathrm{kcal} / \mathrm{mol})$, that is less than $0.5 \mathrm{kcal} / \mathrm{mol}$; consequently the energy gap has been recalculated at the $\operatorname{CCSD}(\mathrm{T})$ level as $0.73 \mathrm{kcal} / \mathrm{mol}$ in order to check the energetic ordering of the two isomers.

Table 4. Relative thermodynamic stability* of nitrile precursors of glycine, alanine and amino butyric acid isomers (kcal/mol).

\begin{tabular}{|c|c|c|c|c|c|}
\hline $\begin{array}{l}\text { Nitrile } \\
\text { Glycine isomers }\end{array}$ & $\Delta \mathrm{E}$ & $\begin{array}{l}\text { Nitrile } \\
\text { Alanine isomers }\end{array}$ & $\Delta \mathrm{E}$ & $\begin{array}{l}\text { Nitrile } \\
\text { ABA isomers }\end{array}$ & $\Delta \mathrm{E}$ \\
\hline $\mathrm{NH}_{2}-\mathrm{CH}_{2}-\mathrm{CN}$ & 0.0 & $\mathrm{NH}_{2}-\mathrm{CH}\left(\mathrm{CH}_{3}\right)-\mathrm{CN}$ & 0.0 & $\mathrm{NH}_{2}-\mathrm{C}\left(\mathrm{CH}_{3}\right)_{2} \mathrm{CN}$ & 0.0 \\
\hline $\mathrm{CH}_{3}-\mathrm{NH}-\mathrm{CN}$ & 3.1 & $\mathrm{NH}_{2}-\mathrm{CH}_{2}-\mathrm{CH}_{2}-\mathrm{CN}$ & 0.4 & $\mathrm{NH}_{2}-\mathrm{CH}\left(\mathrm{CH}_{3}\right)-\mathrm{CH}_{2}-\mathrm{CN}$ & 0.3 \\
\hline $\mathrm{CH}_{3} \mathrm{~N}=\mathrm{C}=\mathrm{NH}$ & 3.3 & $\mathrm{CH}_{3}-\mathrm{CH}_{2}-\mathrm{NH}-\mathrm{CN}$ & 3.4 & $\mathrm{NH}_{2}-\mathrm{CH}_{2}-\mathrm{CH}\left(\mathrm{CH}_{3}\right)-\mathrm{CN}$ & 2.1 \\
\hline $\mathrm{HN}=\mathrm{CH}-\mathrm{CH}=\mathrm{NH}$ & 11.3 & $\mathrm{CH}_{3}-\mathrm{NH}-\mathrm{CH}_{2}-\mathrm{CN}$ & 9.2 & $\mathrm{NH}_{2}-\mathrm{CH}_{2}-\mathrm{CH}(\mathrm{CN}) \mathrm{CH}_{2}-\mathrm{CH}_{3}$ & 2.3 \\
\hline $\mathrm{HN}=\mathrm{CH}-\mathrm{N}=\mathrm{CH}_{2}$ & 13.6 & $\left(\mathrm{CH}_{3}\right)_{2} \mathrm{~N}-\mathrm{CN}$ & 9.5 & $\mathrm{NH}_{2}-\left(\mathrm{CH}_{2}\right)_{3}-\mathrm{CN}$ & 2.4 \\
\hline \multirow[t]{7}{*}{$\mathrm{NH}_{2}-\mathrm{CH}_{2}-\mathrm{NC}$} & 18.5 & & & $\left(\mathrm{CH}_{3}\right)_{2} \mathrm{CH}-\mathrm{NH}-\mathrm{CN}$ & 3.2 \\
\hline & & & & $\mathrm{CH}_{3}-\mathrm{CH}_{2}-\mathrm{CH}_{2}-\mathrm{NH}-\mathrm{CN}$ & 5.9 \\
\hline & & & & $\mathrm{CH}_{3}-\mathrm{NH}-\mathrm{CH}_{2}-\mathrm{CH}_{2}-\mathrm{CN}$ & 8.5 \\
\hline & & & & $\mathrm{CH}_{3}-\mathrm{NH}-\mathrm{CH}\left(\mathrm{CH}_{3}\right)-\mathrm{CN}$ & 8.8 \\
\hline & & & & $\mathrm{CH}_{3}-\mathrm{CH}_{2}-\mathrm{NH}-\mathrm{CH}_{2}-\mathrm{CN}$ & 9.6 \\
\hline & & & & $\mathrm{CH}_{3}-\mathrm{CH}_{2}-\mathrm{N}\left(\mathrm{CH}_{3}\right)-\mathrm{CN}$ & 10.3 \\
\hline & & & & $\left(\mathrm{CH}_{3}\right)_{2} \mathrm{~N}-\mathrm{CH}_{2}-\mathrm{CN}$ & 13.7 \\
\hline
\end{tabular}

* All calculations in this table are carried out at the B3LYP $/ 6-311 \mathrm{G}^{* *}$ level. In view of the low difference $(\Delta \mathrm{E}<0.5 \mathrm{kcal} / \mathrm{mol})$ between the energies of the lowest two isomers of the C3 (Ala) and C4 (ABA) series $(0.43$ and $0.34 \mathrm{kcal} / \mathrm{mol}$ respectively) these energy gaps have been recalculated at higher levels of theory using the B3LYP/6-311G** optimized geometries: Ala: CCSD/cc-pVQZ $=0.52$;

$\operatorname{CCSD}(\mathrm{T}) / / \mathrm{cc}-\mathrm{pVQZ}=0.69(\mathrm{kcal} / \mathrm{mol}), \mathrm{ABA}: \mathrm{CCSD} / \mathrm{cc}-\mathrm{pVQZ}=0.94 ; \mathrm{CCSD}(\mathrm{T}) / / \mathrm{cc}-\mathrm{pVQZ}=1.31(\mathrm{kcal} / \mathrm{mol})$. These numbers confirm the stability of the energetic ordering. 
1). This result, valid in gas phase conditions, says that it is unlikely that their relative abundances, as deduced from the analysis of the organic matter of the meteorites, be related to their presence in the gas phase, which rules out the hypothesis of the accretion of these compounds after they are formed.

Most chondrites suffered extensive transformations on their parent bodies: thermal metamorphism in petrographic types $\mathbf{3}$ and above (only the Allende CV3 in Table 5), and aqueous alteration moderate to severe in petrographic type 2s(Renazzo, Murchison, Murray, Nogoya and Tagish Lake) and extensive in type 1s (Orgueil and Ivuna). Essebi, although classified as an ungrouped type $\mathbf{2}$ is known to also have suffered extensive alteration on its parentbody(Metzler et al. 1992).

It is unlikely that the AA contents of all these chondrites remained unaffected by such processes and still reflect pre-accretionary conditions. Indeed, Table 5 on meteorite falls $^{3}$ shows systematic differences between type $2 \mathrm{~s}$ and the more heavily altered CI1s and Essebi. In the former $\beta$ - and $\alpha$-Ala concentrations average several hundreds up to a thousand $\mathrm{ppb}$ with a close to 1 ratio. In the latter CI1s type, on the other hand, only the concentration of $\beta$-Ala is in that same range, whereas concentrations of $\alpha$-Ala are only $\sim 200 \mathrm{ppb}$. This suggests that $\alpha$-Ala was preferentially destroyed in the alteration conditions that prevailed on the parent CI and Essebi parent bodies. The recent results obtained on the Paris meteorite (Martins et al. (2015))(Martins et al. 2015) show a $\beta / \alpha$ ratio of $\sim$ 0.7-0.9 totally consistent with CM2 petrologic classification.

It is worth noting that meteorite finds, most of which experienced terrestrial weathering, exhibit a totally different pattern (Table 6) while the range of variations appears much larger than in falls, (up to tens of thousands ppb of $\alpha$-Ala in some CR chondrites). The $\beta$-Ala concentration tends to be low (down below the detection limit in a few cases) and almost systematically depleted with respect to $\alpha$-Ala, with a $\beta / \alpha$ ratio $\sim 0.1$, except in a few petrographic type 1 (MET 01070, SCO 06043 and one replicate of GRO 95577). This suggests preferential destruction of $\beta$-Ala in the course of terrestrial weathering (type 1 MET 01070, SCO 06043 and GRO 95577 having presumably started with $\beta$-Ala much higher than $\alpha$-Ala due to previous parent-body alteration).

From the quantum simulations, the minimum energy principle gives that the $\alpha$ - and $\beta$-Ala isomers are the most stable species that can be formed from the $[3 \mathrm{C}, 7 \mathrm{H}, 2 \mathrm{O}, \mathrm{N}]$ set of atoms in only two conditions, namely in protonated or in zwitterionic forms (see Tables 2 and 3). However, it is remarkable that the stability order is not the same in both cases. Additional information on the nature of the parent bodies of the carbonaceous chondrites can be obtained with the values of the relative abundances of the $\mathrm{ABA}$ isomers

\footnotetext{
3 Falls means that the date of the fall is known and the meteorite collected soon after. Finds means that the date when the meteorite was found is known but that the time during which it has been exposed to the terrestrial environment is unknown.
}

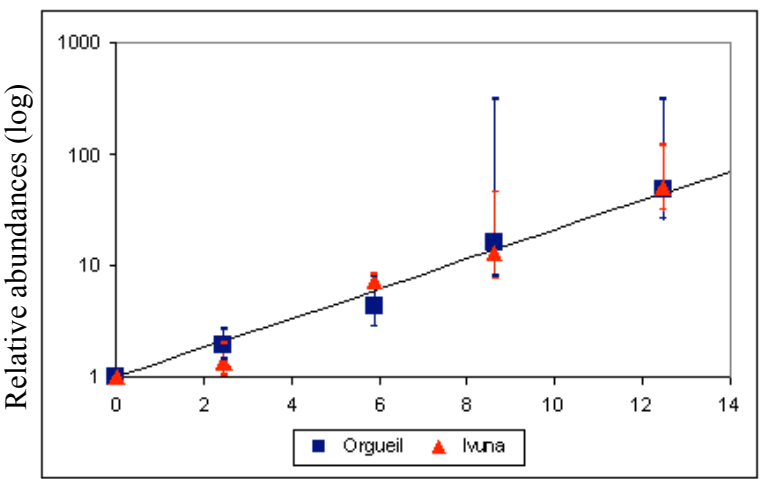

Relative energies with respect to $\gamma$-ABA

Figure 1. Relative abundances of the $5 \mathrm{C}_{4} \mathrm{H}_{9} \mathrm{NO}_{2}$ isomers present in chondrites Orgueil and Ivuna as a function of the energy gap ( $\mathrm{kcal} / \mathrm{mol})$ to the most stable protonated isomer

according to the type of chondrite from which they are extracted.

The work of Guo \& Eiler (2007)(Guo \& Eiler 1994) demonstrates indeed that the hydration phase lasted long enough to reach a local thermodynamic equilibrium both in $\mathrm{CM}$ and in CI chondrites. It is a perfect situation for PEM application as a pragmatic tool on the relative abundances of ABA isomers in protic (Ivuna, Orgueil) and neutral (Murchison, Murray) environments respectively. Unfortunately, all the ABA isomers necessary to assist in the characterization of Paris have not been identified in the laboratory. Anyhow there are enough data to single out typical examples of $\mathrm{CM}$ and CI meteorites for the comparison of the relative abundances with the relative stabilities as a function of the environment.

\subsection{Amino acids in CI carbonaceous chondrites}

The AA abundances determined in CI chondrites Orgueil and Ivuna(Ehrenfreund et al. 2001; Martins \& Sephton 2009) are very similar. According to our calculations the most abundant is Gly followed by $\beta$-Ala and $\gamma$-ABA in a protic environment. These AA are indeed the most stable species that can be formed as protonated species from the $[2 \mathrm{C}, 5 \mathrm{H}, 2 \mathrm{O}, \mathrm{N}] \mathrm{H}^{+},[3 \mathrm{C}, 7 \mathrm{H}, 2 \mathrm{O}, \mathrm{N}] \mathrm{H}^{+}$and $[4 \mathrm{C}, 9 \mathrm{H}, 2 \mathrm{O}, \mathrm{N}] \mathrm{H}^{+}$ sets of atoms (Table 1).

It can be seen that $\beta$ - $\mathrm{Ala}\left(\mathrm{H}^{+}\right)$is more stable than biological $\alpha$-Ala $\left(\mathrm{H}^{+}\right)$. In the same way, when comparing the abundance ordering of AA of $\mathrm{C}_{4} \mathrm{H}_{9} \mathrm{NO}_{2}$ raw formula identified by analysis of the organic matter in CI chondrites with the stability ordering of the corresponding protonated species, we find the same ordering. It can be concluded that, in the case of CI chondrites, the more stable is the protonated $\mathrm{AA}\left(\mathrm{H}^{+}\right)$, the larger should be the abundance of the corresponding neutral AA; it is what is effectively observed according to laboratory analyses, i.e. $\beta$-Ala and $\gamma$-ABA for $3 \mathrm{C}$ and $4 \mathrm{C}$ AA respectively.

Another point to outline is the perfect similarity of the abundance ratios of the higher energy isomers to that of the most abundant $\gamma$-ABA in both Ivuna and Orgueil. Regardless of the uncertainties on the measured abundances Figure 1 shows that there is a linear relation between the relative energies of the protonated isomers and the abundances of 
$[$ [htb]

Table 5. Average concentrations of glycine, $\alpha$ - and $\beta$-alanine in carbonaceous falls (ppb) taken from Botta et al. (2002), Botta et al. (2007), Martins \& Sephton (2009), Glavin et al. (2011) and Martins et al. (2015) together with ( $\beta$-Ala)/( $\alpha$-Ala) abundance ratios.

\begin{tabular}{|c|c|c|c|c|c|c|}
\hline Meteorite & Type & glycine & $\alpha$-alanine & $\beta$-alanine & $\beta / \alpha$ & Ref \# \\
\hline Allende & CV3 & 457 & 131 & 317 & 2.4 & $\operatorname{MS}(2009)$ \\
\hline Renazzo & CR2 & 875 & 170 & 223 & 1.3 & $\operatorname{MS}(2009)$ \\
\hline Mighei & CM2 & 788 & 587 & 897 & 1.5 & $\operatorname{MS}(2009)$ \\
\hline \multirow[t]{4}{*}{ Murchison } & CM2 & 2919 & 888 & 809 & 0.9 & $\operatorname{Bot}(2007)$ \\
\hline & & & 1676 & 1269 & 0.8 & $\operatorname{Bot}(2002)$ \\
\hline & & & 1310 & 1081 & 0.8 & Gla(2011) \\
\hline & & & 1282 & 1419 & 1.1 & Gla(2011) \\
\hline Murray & CM2 & 2110 & 1264 & 1063 & 0.8 & MS (2009) \\
\hline Nogoya & CM2 & 1118 & 457 & 796 & 1.7 & MS (2009) \\
\hline Paris non hydrolyzed & $\mathrm{CM}(2.7 / 2.8)$ & & 729 & 620 & 0.85 & Mar (2015) \\
\hline Paris hydrolyzed & $\mathrm{CM}(2.7 / 2.8)$ & & 1671 & 1250 & 0.71 & $\operatorname{Mar}(2015)$ \\
\hline Tagish Lake & $\mathrm{C} 2$ & 147 & 95 & 64 & 0.7 & MS(2009) \\
\hline Essebi & C2-ung & 495 & 241 & 1396 & 5.8 & $\operatorname{MS}(2009)$ \\
\hline Ivuna & CI1 & 617 & 239 & 1401 & 5.9 & $\operatorname{MS}(2009)$ \\
\hline \multirow[t]{3}{*}{ Orgueil } & CI1 & 707 & 174 & 2732 & 15.7 & Gla (2011) \\
\hline & & & 235 & 1579 & 6.7 & $\operatorname{Bot}(2002)$ \\
\hline & & & 235 & 1579 & 6.7 & $\operatorname{Bot}(2007)$ \\
\hline
\end{tabular}

Table 6. Average concentrations of $\alpha$ - and $\beta$-alanine in carbonaceous finds (ppb) taken from Botta et al. (2002), Botta et al. (2007), Martins \& Sephton (2009), Glavin et al. (2011) and Martins et al. (2015) together with $(\beta$-Ala)/( $\alpha$-Ala) abundance ratios.

\begin{tabular}{lccccc}
\hline \hline Meteorite & Type & $\alpha$-alanine & $\beta$-alanine & $\beta / \alpha$ & Ref \# \\
\hline ALH83100 & CM2 & 244 & 338 & 1.5 & MS(2009)) \\
ALHA77306 & CM2 & 160 & 160 & 0.9 & MS(2009) \\
B-7904 & CM2 & 2 & 1 & & MS(2009) \\
LEW90500 & CM2 & 695 & 442 & 0.6 & Gla(2006) \\
LON94102 & CM2 & 1568 & 821 & 0.5 & Gla(2011) \\
Y-74662 & CM2 & & 1247 & & MS(2009)) \\
Y-79331 & CM2 & & 4 & & MS(2009) \\
Y-791198 & CM2 & 5808 & 1425 & 0.2 & MS(2009) \\
ALH88045 & CM1 & 994 & 197 & 0.2 & MS(2009) \\
LAP0227 & CM1 & 429 & 16 & 0.0 & MS(2009) \\
MET01070 & CM1 & 39 & 187 & 4.8 & Gla (2011) \\
SCO99077 & CM1 & 20 & 122 & 6.1 & Gla (2011) \\
QE 99177 & CR3 & 7133 & 1954 & 0.3 & Gla(2011) \\
EET 92042 & CR2 & 43961 & 3046 & 0.1 & MS(2009) \\
& & 81433 & 4161 & 0.1 & GlaD(2009) \\
GRA 95229 & CR2 & 103606 & 3143 & 0.0 & MS(2009) \\
Shisr 033 & CR2 & 604 & 62 & 0.1 & MS(2009) \\
GRO 95577 & CR1 & 170 & 122 & 0.7 & MS(2009)) \\
& & 81 & 295 & 3.6 & Gla(2011) \\
\hline
\end{tabular}

the corresponding neutral AA. The slope of the regression line $(\sim 0.3)$ is the same for Ivuna and Orgueil ${ }^{4}$. Such ev-

\footnotetext{
${ }^{4}$ Error bars in Figures 1-3 are determined as the range of the ratios between the highest and lowest values measured for the isomer considered and the mean value measured for the most abundant isomer
}

idence leads to consider that the abundances of AA in CI chondrites are linked to the energies of the $\mathrm{AA}\left(\mathrm{H}^{+}\right)$species by a type of Boltzmann relation, which is totally consistent with the state of local thermodynamic equilibrium.(Guo \& Eiler 1994) 
Table 7. Abundances (in ppb) of the AA isomers of $\mathrm{C}_{4} \mathrm{H}_{9} \mathrm{NO}_{2}$ (upper panel) and $\mathrm{C}_{3} \mathrm{H}_{5} \mathrm{NO}_{2}$ (lower panel) present in chondrites Orgueil and Ivuna. Abundance ratios of the most abundant isomer $\gamma$-ABA and $\beta$-Ala to the other detected AA: $(\gamma$-ABA)/(other ABA isomers) and $(\beta$-Ala $) /\left(\right.$ other Ala isomer); relative energies $(\mathrm{kcal} / \mathrm{mol})$ of the corresponding protonated derivatives $\Delta \mathrm{E}\left(\mathrm{AA}\left(\mathrm{H}^{+}\right)\right.$

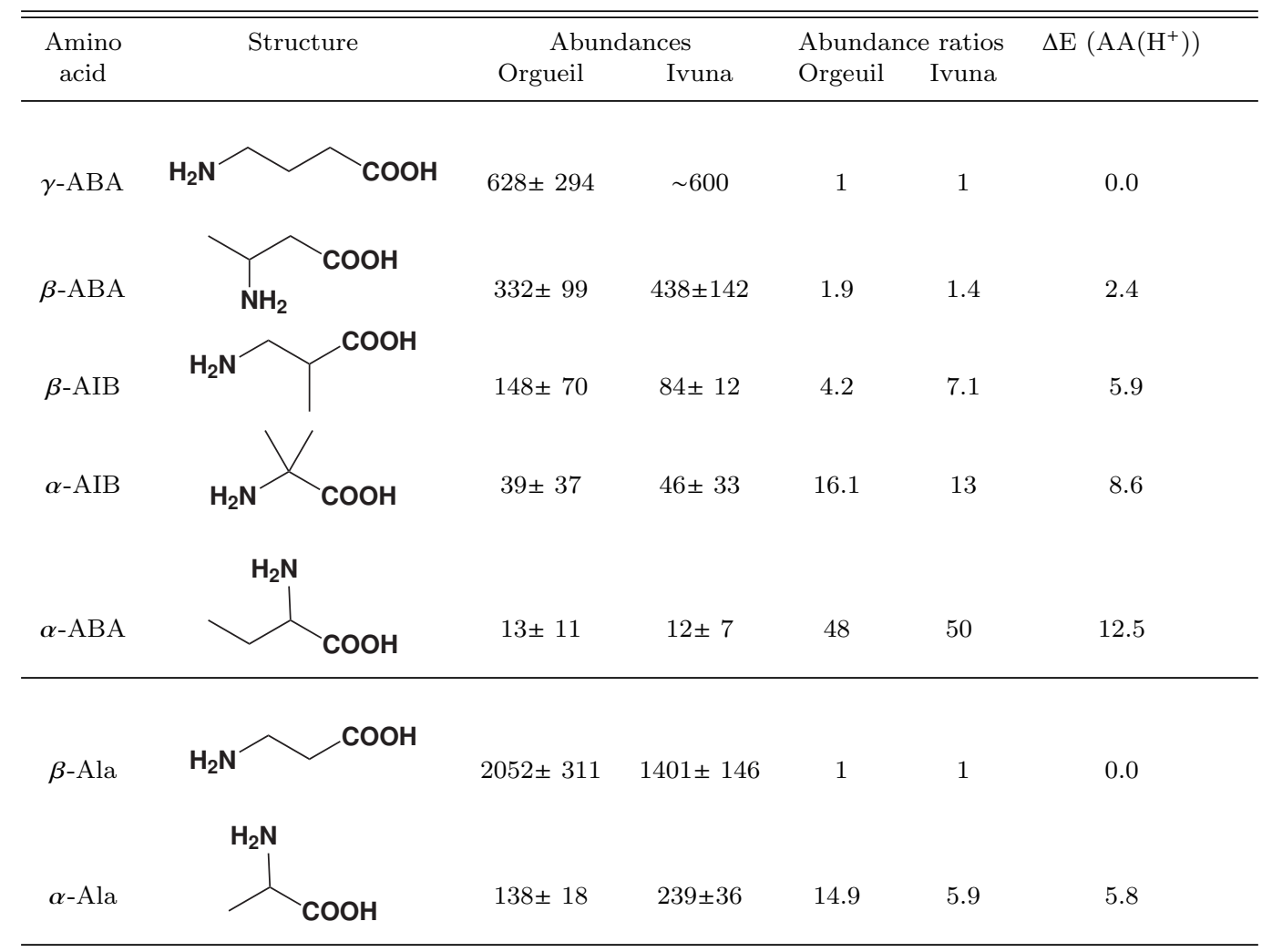

\subsection{Amino acids in CM carbonaceous chondrites}

The AA abundances determined in CM chondrites(Ehrenfreund et al. 2001; Martins \& Sephton 2009) as Murchison, Murray are very different from those in CI. In addition to Gly, the most abundant is $\alpha$-AIB, the $\alpha$-Ala and $\beta$-Ala isomers being a little less abundant though close to each other as measured in the laboratory analyses of the organic matter. The situation is summarized in Table 8 and Figures 3 and 4.

In a neutral water environment, that favors the zwitterionic structures, $\alpha$-Ala is more stable than the $\beta$-isomer and for the same energetic reason should be more abundant. It is precisely what is found in meteorite finds listed in Table 6 that experienced terrestrial weathering.

The unweathered and least parent-body altered(Rubin et al. 2011) CM2 Murchison and Murray have concentrations of both $\alpha$ - and $\beta$-Ala in the thousand ppb range. As pointed above, this is unlikely to reflect a pre-accretionary process that would take place in gas phase conditions as $\alpha$ - and $\beta$-Ala are far from being the most stable isomers that can be formed. It is more likely to reflect the initial Ala global budget of the rocks synthetized in neutral to slightly acidic conditions, either at the onset of parent-body alteration at the expense of a more stable isomer inherited from the gas phase, or in a yet to be determined environment such as within CHON-bearing irradiated ices.

The large quantity of $\alpha$-AIB (comparable to Gly) found in CM chondrites has led Miller and co-workers (Wolman et al 1972) to suggest that Strecker synthesis can be the dom-

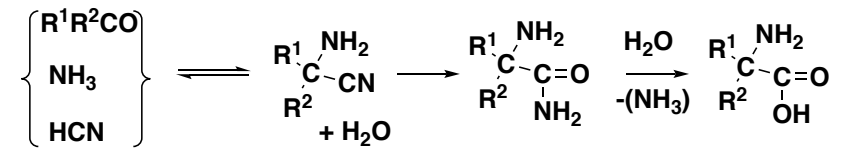

Figure 2. Strecker reaction leading after hydrolysis to $\alpha$-amino acids inside the meteorites parent bodies of CM chondrites; generally $\mathrm{R}^{1}$ and $\mathrm{R}^{2}$ are carbonaceous fragments (if $\mathrm{R}^{1}=\mathrm{R}^{2}=\mathrm{H}$, the AA obtained is glycine)

inant mechanism of AA formation in these types of meteorites. The reaction between $\mathrm{HCN}, \mathrm{NH}_{3}$ and carbonyl compounds leads to an equilibrium in aqueous solution between cyanohydrines and aminonitriles, these intermediates giving $\alpha$-amino-acids irreversibly upon hydrolysis. These reactions are supposed to take place in the meteorites parent bodies.

Considering the plots of the abundances of AA versus the energy separations in Figures 3 and 4 suggests the existence of a quasi linear relation in Murchison and Murray between higher energy isomers and that of the most stable $\alpha$-AIB, this being valid for both the zwitterions and the corresponding aminonitriles precursors. In both cases, the regression lines are very close with values of $\sim 0.6$ and $\sim 0.9$ for zwitterions and aminonitriles, respectively. It confirms that the relative distribution of the $\mathrm{AA}$ isomers is equivalent in the two CM chondrites and makes to think of a direct filiation between the aminonitriles and the direct AA derivative. 
Table 8. Abundances (in ppb) of the AA isomers of $\mathrm{C}_{4} \mathrm{H}_{9} \mathrm{NO}_{2}$ (upper panel) and $\mathrm{C}_{3} \mathrm{H}_{5} \mathrm{NO}_{2}$ (lower panel) present in chondrites Murchison and Murray. Abundance ratios of the most abundant isomer $\alpha$-AIB and $\beta$-Ala to the other detected AA: ( $\alpha$-AIB)/(other ABA isomers) and $\left(\beta\right.$-Ala)/(other Ala isomer). Relative energies $(\mathrm{kcal} / \mathrm{mol})$ of the corresponding zwitterionic $\Delta \mathrm{E}\left(\mathrm{A}^{+} \mathrm{A}^{-}\right)$and nitrile precursors $\Delta \mathrm{E}$ $(\mathrm{CN})$

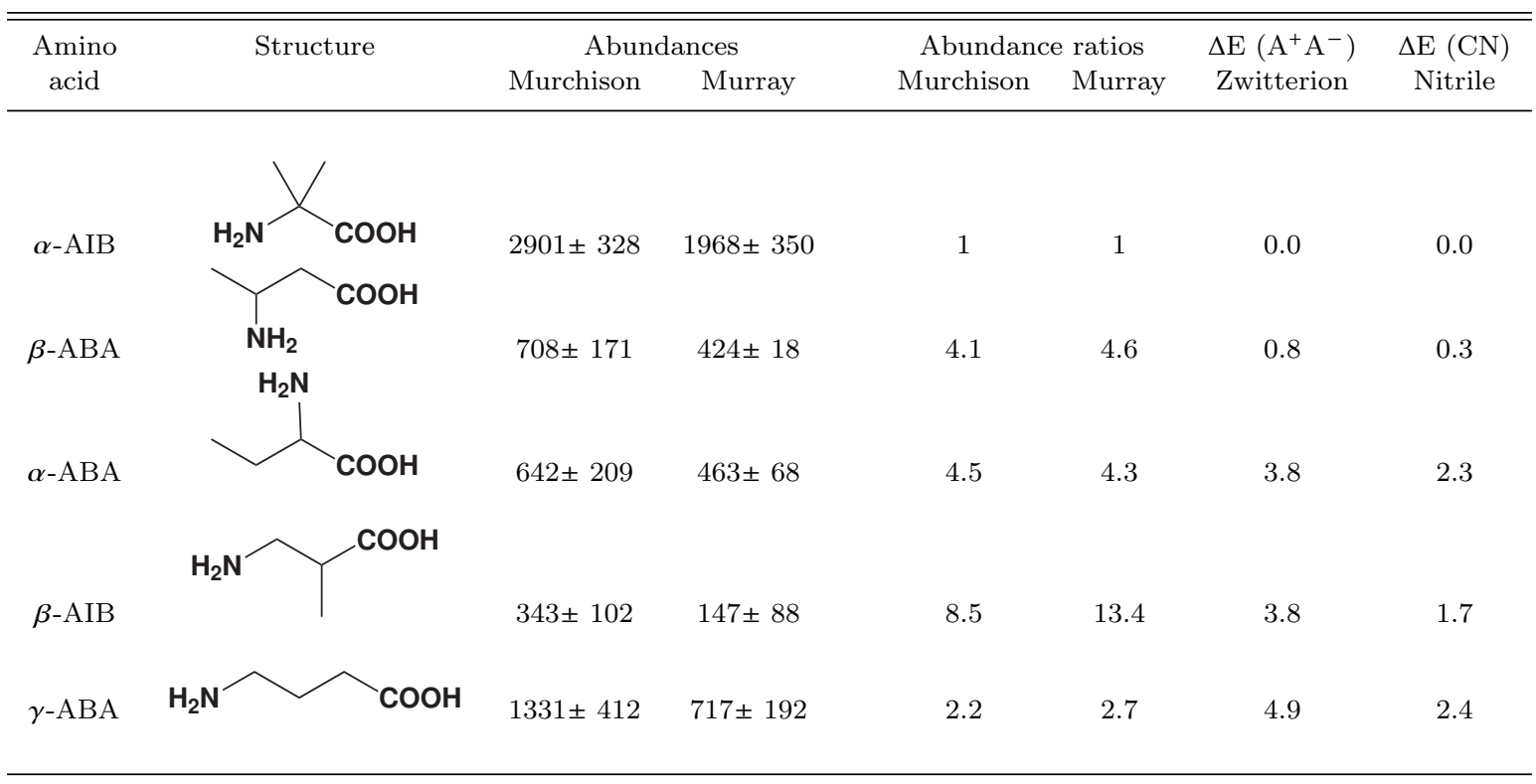

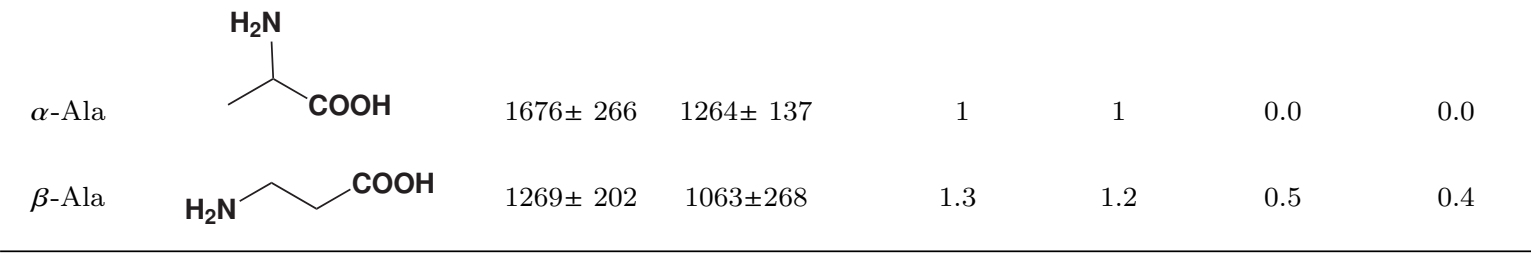

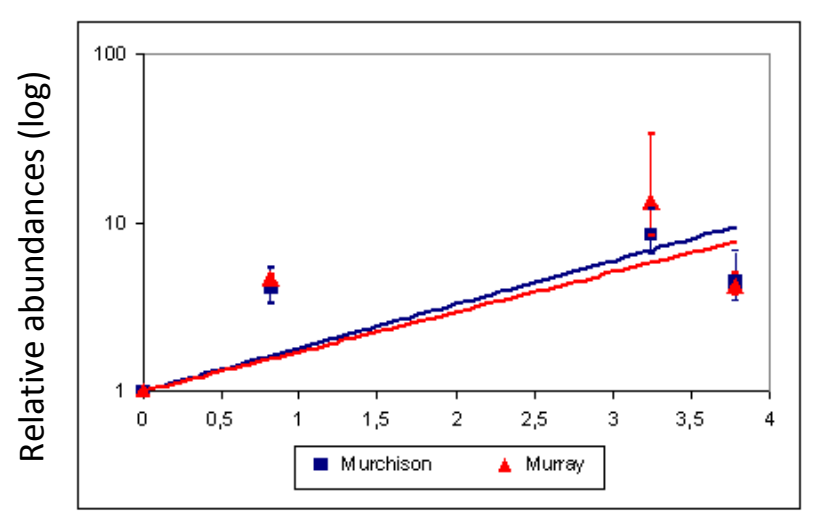

Relative abundances with respect to $\alpha$-AIB zwitterion

Figure 3. Relative abundances of 4 isomers of $\mathrm{C}_{4} \mathrm{H}_{9} \mathrm{NO}_{2}$ formula present in chondrites Murchison and Murray as a function of the energy gap $(\mathrm{kcal} / \mathrm{mol})$ to the most stable zwitterionic isomer: $\alpha$ AIB. The $\gamma$-ABA isomer is not considered in these plots: see text below.

We remark that the correlation coefficients in the CMs are smaller than in the case of the protonated AA in the CIs. However, even with larger uncertainty margins, it is still possible to consider that the abundances of the AA are approximately distributed in a Boltzmanian way relative to

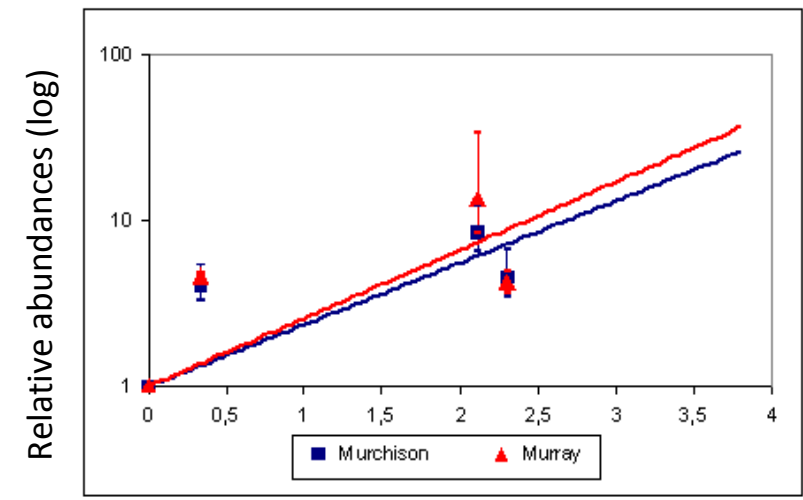

Relative abundances with respect to $\alpha$-AIB nitrile

Figure 4. Relative abundances of 4 isomers of $\mathrm{C}_{4} \mathrm{H}_{9} \mathrm{NO}_{2}$ formula present in chondrites Murchison and Murray as a function of the energy gap $(\mathrm{kcal} / \mathrm{mol})$ to the most stable nitrile isomer: $\alpha$-AIB. The $\gamma$-ABA isomer is not considered in these plots: see text below.

their stabilities in the environments. The distance to linearity found in this study might be due to a weakness of the theoretical representation of the conjectured liquid medium which is most probably not pure water inside the parent bodies. Despite being one of the more realistic models to represent solute - solvent electrostatic interactions, taking 
the solvent as a continuous medium cannot accurately account for the dynamical aspect of hydrogen bonds.

How relevant is the energetic ordering calculated for the AA nitriles on their respective energy scales is a crucial information. Rising the level of theory from B3LYP to CCSD and $\operatorname{CCSD}(\mathrm{T})$ to account for more electronic correlation confirms the stability ordering of the lowest two energy isomers in the $\mathrm{C} 3$ (Ala) and $\mathrm{C} 4(\mathrm{ABA})$ nitrile series, that is to say, that $\mathrm{NH}_{2} \mathrm{CH}\left(\mathrm{CH}_{3}\right) \mathrm{CN}$ and $\mathrm{NH}_{2}-\left(\mathrm{CH}_{3}\right)_{2}-\mathrm{CN}$ are more stable than $\mathrm{NH}_{2} \mathrm{CH}_{2} \mathrm{CH}_{2} \mathrm{CN}$ and $\mathrm{NH}_{2}-\mathrm{CH}\left(\mathrm{CH}_{3}\right)_{2}-\mathrm{CN}$.

The case of zwitterions could be more complex, in fact less tractable, since the energies had yet been evaluated with large basis sets due to the necessary inclusion of diffuse functions for describing the liquid environment, as well as higher level of theory. Yet, the only questionable point, i.e. the gap between the isomers of the Ala series has been recalculated at the $\operatorname{CCSD}(\mathrm{T})$ level as for the sensitive points of the nitrile case. These calculations confirm that $\mathrm{NH}_{3}^{+} \mathrm{CH}\left(\mathrm{CH}_{3}\right) \mathrm{COO}^{-}$ is more stable than the $\mathrm{NH}_{3}^{+} \mathrm{CH}_{2} \mathrm{CH}_{2} \mathrm{COO}^{-}$isomer.

In the discussion of $\mathrm{AA}$ in $\mathrm{CM}$ chondrites we have not considered $\gamma$-ABA whose large abundance falls out the pattern shown by the other four isomers (Table 8). At least two reasons can be mentioned for explaining this surprising observation. Following Glavin et al. (1999), it could be traced back to the fact that this compound is known to be a wide spread terrestrial contaminant of bacterial origin. Beyond a biochemical source, rather unlikely to apply in the case of meteorite falls, we prefer to consider a kinetic origin, namely that the large abundance of $\gamma$-ABA could also be due to a large activation barrier creating an energetic well preventing rearrangement towards a more stable structure; $\gamma$-ABA is linear whereas all the other isomers are ramified.

The fact that the only AA precursor detected in the ISM i.e. $\mathrm{NH}_{2} \mathrm{CH}_{2} \mathrm{CN}$ (precursor of Gly) in Sg B2 (Belloche et al. $2008)$ ) is the most stable molecule of the $[2 \mathrm{C}, 4 \mathrm{H}, 2 \mathrm{~N}]$ series is consistent with the MEP of Lattelais et al, (2009, 2010). It is a strong incentive to the search for the most stable C3 amino nitrile $\mathrm{NH}_{2} \mathrm{CHCH}_{3} \mathrm{CN}$, the first chiral $\alpha$-aminonitrile that would lead to the first chiral AA.

\section{CONCLUSION}

One has first to recall that the thermodynamically most stable compounds are those kinetically stable in standard conditions on the Earth. Then, before drawing any conclusion for meteorites it should also be reminded that this study relies on two types of a priori disconnected data, namely, laboratory experiments on the meteoritic organic matter and theoretical quantum calculations.

On the one hand, the laboratory analysis of the organic matter of carbonaceous chondrites, from which the AA abundances are deduced, is performed after extractions in harsh acidic conditions. In these circumstances, original functional groups can be strongly altered so that the primary nature of the AA functionality has been erased. The best example is that of $\alpha$-amino nitriles which cannot survive as such the acidic extraction and are irreversibly transformed into the corresponding AA. Such drastic chemical modification may have dramatic consequences in that, the abundances deduced from the analysis are not those of the original AA but the addition of all those of the precursors that are transformed into AA in the process of acidic extraction. For instance, aminoacetonitrile, a precursor of glycine, has been detected in the ISM (Belloche et al. 2008) but never identified in meteorites whereas glycine is a major component found in carbonaceous chondrites.

On the other hand the numerical simulations are able to track from scratch the most plausible structures before (gas phase) and during (water conditions) the hydration phase, namely neutral, protonated, zwitterionic as well as that of the nitrile precursors.

Relying on the work that showed that the hydration phase lasted long enough to reach a local thermodynamic equilibrium both in CM and in CI chondrites we are confident in the ability of the PEM as a pragmatic tool to predict the relative stabilities of the possible isomeric structures not identifiable in situ. In the end, two working hypotheses can be presented according the type of chondrite, CI or CM.

i) For CIs, the present work suggests that after synthesis in neutral to slightly acidic conditions, Ala was partly destroyed in physico-chemical conditions that were rather acidic in parent-body altered Orgueil, Ivuna and Essebi. In this case we have to suppose that the surrounding medium was adequately acidic for the AA be present mostly in a protonated form, that is with a $\mathrm{pH} \sim 2$, i.e. a typical value for the carboxylic function of an amino acid. Terrestrial weathering, on the other hand, was also responsible for the partial destruction of Ala, but took place in a more neutral meteoritic aqueous environment.

ii) For CMs, we have to suppose that the surrounding medium was neutral or slightly basic for amino acids and amino nitriles to be present in the parent bodies. This situation tends to demonstrate that the $\mathrm{pH}$ of the aqueous phase should be comprised in the range of 2 and 10, i.e. an interval typical of the separation between the pK of the carboxylic and amino functions of an amino acid. It is compatible with the study by Dufresne \& Anders, almost 60 years ago, reporting a $\mathrm{pH}$ interval between 6 and 10 for the aqueous phase for the CM chondrites(Dufresne \& Anders 1962).

Finally, on the basis of our relative stability simulations, the presence or not of a protic environment that can be deduced from the $\alpha$ - to $\beta$-alanine abundance ratio and more certainly from the relative abundances of the ABA isomers in unweathered falls could thus be considered as an additional criterion to constrain the nature of the parent bodies of carbonaceous chondrites.

\section{ACKNOWLEDGEMENTS}

This work was supported by the Programme National Physique et Chimie du Milieu Interstellaire (PCMI) of CNRS/INSU with INC/INP co-funded by CEA and CNES. Also acknowledged is the support of COST Action CM0805 (The Chemical Cosmos). J.-C.G. thanks the CNES for financial support.

Data Availability Statement

The data underlying this article were generated by using Quantum Chemistry packages Gaussian 09 and VASP currently used by the computational chemists community and available in the public domain. References of the codes are given in the article. 


\section{REFERENCES}

Belloche A., Menten K.M., Comito C., Müller H.S.P., Schilke P., Ott J., Thorwirth S., \& Hieret C. (2008) Astron. Astrophys., 482, 179

Bernstein M.P., Ashnourn S.F.M., Sandford S.A., \& Allamandola L.J. (2004) ApJ., 601, 365.

Botta O., Glavin D. P., Kminek G.,\& Bada J. L. (2002) Orig. Life Evol. Biosph., 32, 143

Botta O., \& Bada J. L. (2002) Extraterrestrial Organic Compounds in Meteorites, Surv. Geophys., 23, 411

Botta O., Martins Z., \& Ehrenfreund P. (2007) Meteoritics \& Planetary Science, 42,81

Brown R.D., Godfrey P.D., Ottrey A.L., \& Storey J.W.V. (1977) J.Mol. Spectrosc., 68, 359

Chiaramello J. M., Talbi D., Berthier G., \& Ellinger Y. (2005) Int J Astrobiol 4, 125

Cooper G. W., Onwo W. M., \& Cronin J. R. (1992) Geochim. Cosmochim. Acta, 56, 4109

Cronin J. R., \& Chang S. (1993) Organic Matter in Meteorites: Molecular and Isotopic Analyses of the Murchison Meteorites in The Chemistry of Life Origin, Eds. Greenberg, J. M., Mendoza-Gomez, C. X. \& Pirronello, V. (Kluwer, Dordrecht, The Netherlands), p. 209

Cronin J. R., Cooper G. W., \& Pizzarello S. (1995) Adv. Space Res., 15, 91

Dufresne E.R., \& Anders E. (1962) Geochim. Cosmochim. Acta, 26,1083

Ehrenfreund P., Glavin D. P., Botta O., Cooper G., \& Bada J. L. (2001) Proc. Natl. Acad. Sci. U.S.A., 98, 2138

Ellinger Y., Pauzat F., Markovits A., Allaire A., \& Guillemin J.-C. (2020) Astron. Astrophys., 633, A49

Elsila, J. E., Aponte, J. C., Blackmond, D. G., Burton, A. .S., Dworkin, J. P., \& Glavin, D. P. (2016) ACS. Cent. Sci., 2, 370

Frish, M., Trucks, G., Schlegel, H. et al. 2009, Gaussian 09, Rev.A.02, Gaussian Inc., Wallingford CT., 06492

Glavin D. P., Bada J.L., Brinton K.L.F., \& McDonald G.D. (1999) Proc. Natl. Acad. Sci. U.S.A. 26, 8835.

Glavin D. P., Callahn M. P., Dworkin J. P., \& Elsila J. E. (2011) Meteoritics \& Planetary Science, 45, 1948

Guo W., \& Eiler J. M. (2007) Geochim. Cosmochim. Acta 71, 5565

Kassab, E., Langlet J., \& Evleth E. (2000) J. Mol. Struct. Theochem, 531, 267

Koch W., \& Holthausen M. C. (2001) A Chemist Guide to Density Functional Theory (Weinheim, Germany: Wiley-VCH) 2nd edn.

Kvenvolden, K., Lawless, J., Pering, K., Peterson, E., Flores, J., Ponnamperuma, C., Kaplan, I. R., \& Moore, C. (1970) Nature, 228, 923

Lattelais M., Pauzat F., Ellinger Y., \& Ceccarelli C. (2009) Astrophys J Lett., 696, L133

Lattelais M., Pauzat F., Ellinger Y., \& Ceccarelli C. (2010) Astron. Astrophys., 519, A30

Lattelais M., Bertin M., Mokrane H., et al. (2011a) Astron. Astrophys., 532, A12

Lattelais M., Pauzat F., Pilmé J., Ellinger Y., \& Ceccarelli C. (2011b) Astron. Astrophys., 532, A39

Lee T. J., \& Scuseria G. E. (1995) in Quantum mechanical electronic structure calculations with chemical accuracy, Ed. Langhoff S. R. (Dordrecht, The Netherlands: Kluwer Academic Publishers).

Martins Z., \& Sephton M. A. (2009) Amino Acids, Peptides and Proteins in Organic Chemistry. Vol.1- Origins and Synthesis of Amino Acids, ed. Hughes AB, (Weinheim, Germany: Wiley$\mathrm{VCH})$ p. 3

Martins, Z., Modica, P., Zanda, B., \& d'Hendecourt, L. (2015)
Meteoritics \& Planetary Science, 50, 926

Metzler K., Bischoff A., \& Stöffler D. (1992) Geochim. Cosmochim. Acta, 56, 2873

Oro, J., Gibert, J., Lichtenstein, H., Wikstrom, S., \& Flory, D. A. (1971) Nature, 230, 105

Peltzer E.T., Bada J.L., Schlesinger G., Miller S.L., Schilke P., Ott J., Thorwirth S., \& Hieret C. (1984) Advances in Space Research, 4, 69

Pizzarello S., Huang Y., \& Fuller M. (2004) Geochim. Cosmochim. Acta 68, 4963

Rubin A. E., Trigo-Rodriguez J. A., Huber H., \& Wasson J. T. (2007) Geochim. Cosmochim. Acta, 71, 2361.

Tomasi J., \& Persico M. (1994) Molecular interactions in solution: An overview of methods based on continuous distributions of the solvent. Chem. Rev., 94, 2027

Vinogradoff, V., Le Guillou, C., Bernard, S., Binet, L., Cartigny, P, Bearley, A. J., \& Remusat, L. (2017) Geochim. Cosmochim. Acta, 212, 234

This paper has been typeset from a $\mathrm{T}_{\mathrm{E}} \mathrm{X} / \mathrm{LAT}_{\mathrm{E}} \mathrm{X}$ file prepared by the author. 